\section{Extremophiles}

November 2007, Volume 11 (6) : Pages 747-757

http://dx.doi.org/10.1007/s00792-007-0092-z

(c) 2007 Springer. Part of Springer Science+Business

Media

The original publication is available at http://www.springerlink.com
Archimer, archive institutionnelle de l'Ifremer http://www.ifremer.fr/docelec/

\title{
Continuous enrichment cultures: insights into prokaryotic diversity and metabolic interactions in deep-sea vent chimneys
}

\author{
Anne Postec ${ }^{1,3,{ }^{\star}}$, Françoise Lesongeur ${ }^{1}$, Patricia Pignet ${ }^{1}$, Bernard Ollivier ${ }^{2}$, Joël Querellou ${ }^{1}$ and Anne \\ Godfroy ${ }^{1}$
}

\author{
${ }^{1}$ Laboratoire de Microbiologie des Environnements Extrêmes, UMR 6197, IFREMER, Centre de Brest, BP 70, \\ 29280 Plouzané, France \\ ${ }^{2}$ Laboratoire IRD de Microbiologie des Anaérobies, UR 101, Universités de Provence et de la Méditerranée, \\ CESB-ESIL, case 925, 163 avenue de Luminy, 13288 Marseille, France \\ ${ }^{3}$ Geologisches Institut, ETH Zentrum, Universitätsstrasse 16, 8092 Zürich, Switzerland
}

*: Corresponding author : A. Postec, email address : anne.postec@univ-brest.fr

\begin{abstract}
:
The prokaryotic diversity of culturable thermophilic communities of deep-sea hydrothermal chimneys was analysed using a continuous enrichment culture performed in a gas-lift bioreactor, and compared to classical batch enrichment cultures in vials. Cultures were conducted at $60^{\circ} \mathrm{C}$ and $\mathrm{pH} 6.5 \mathrm{using} \mathrm{a}$ complex medium containing carbohydrates, peptides and sulphur, and inoculated with a sample of a hydrothermal black chimney collected at the Rainbow field, Mid-Atlantic Ridge, at 2,275 m depth. To assess the relevance of both culture methods, bacterial and archaeal diversity was studied using cloning and sequencing, DGGE, and whole-cell hybridisation of 16S rRNA genes. Sequences of heterotrophic microorganisms belonging to the genera Marinitoga, Thermosipho, Caminicella (Bacteria) and Thermococcus (Archaea) were obtained from both batch and continuous enrichment cultures while sequences of the autotrophic bacterial genera Deferribacter and Thermodesulfatator were only detected in the continuous bioreactor culture. It is presumed that over time constant metabolite exchanges will have occurred in the continuous enrichment culture enabling the development of a more diverse prokaryotic community. In particular, $\mathrm{CO} 2$ and $\mathrm{H} 2$ produced by the heterotrophic population would support the growth of autotrophic populations. Therefore, continuous enrichment culture is a useful technique to grow over time environmentally representative microbial communities and obtain insights into prokaryotic species interactions that play a crucial role in deep hydrothermal environments.
\end{abstract}

Keywords: Microbial diversity - Deep-sea hydrothermal vent-Continuous enrichment cultures Bioreactor - Thermophiles - 16S rRNA gene - Metabolic interactions 
Introduction

The widespread application of $16 \mathrm{~S}$ rRNA gene based molecular methods to identify microorganisms in natural samples has revealed an extensive and, in many cases, unexpected microbial diversity. Within deep-sea hydrothermal environments, the diversity of microbial communities associated with in situ colonizers (McCliment et al. 2006), mats (Moussard et al. 2006), animals (DeChaine et al. 2006), sediments (Inagaki et al. 2006) and chimneys (Kormas et al. 2006) have been reported in recent molecular surveys. The rise of molecular microbial ecology has resulted in the detection of many microorganisms that have as yet not been cultivated, for example the widespread Marine Crenarchaeota Group I (MGI) and the Korarchaeota. To understand the physiology and ecological significance of these uncultivated microorganisms, an effort has to be made to improve and develop cultural approaches. Indeed, culture conditions routinely used reveal only a small fraction of the global microbial community. As an alternative to batch cultures in vials, a gas -lift bioreactor was developed to grow anaerobic and hyperthermophilic microorganisms in continuous culture (Raven et al. 1992). Recently, it has been used to study the metabolism of members of the Thermococcales, including Pyrococcus abyssi (Godfroy et al. 2000), to develop minimal media and to optimize the growth conditions of Pyrococcus furiosus and Thermococcus hydrothermalis (Raven and Sharp 1997; Postec et al. 2005a). In addition to the study of pure cultures, the gas-lift bioreactor can also be used to cultivate representative microorganisms from environmental samples in continuous enrichment culture under controlled conditions. The bioreactor allows the long-term cultivation of microbes by enabling a continuous substrate supply, the elimination of volatile metabolic end-products (potentially toxic for microbial growth) by gas sparging and $\mathrm{pH}$ and temperature regulation. These features help to grow less dominant microorganisms having poor representation, long latency phase and/or slow growth. In a previous study, the gas -lift bioreactor was used to enrich microorganisms from a black smoker collected at $2275 \mathrm{~m}$ depth on the Rainbow hydrothermal field of the Mid-Atlantic Ridge (Postec et al. 2005b). A fifty-days continuous culture at $90^{\circ} \mathrm{C}$ on a rich medium containing sulphur under anaerobic conditions demonstrated a large diversity inside the cultivated community, including (in addition to archaeal species belonging to the order Thermococales) moderately thermophilic members of the orders Clostridiales and Thermotogales, and members of the Epsilonproteobacteria that were not detected in vial cultures. In the present study, the same black smoker chimney was used as inoculum to perform similar experiments on both batch and continuous enrichment cultures under the same conditions, except the temperature lowered to $60^{\circ} \mathrm{C}$. The 
techniques based on the 16S rRNA genes: cloning, sequencing, denaturing gradient gel electrophoresis (DGGE) and whole-cell hybridisation. Molecular results were the guidelines for subsequent isolation of microorganisms from the enrichment cultures.

\section{Materials and methods}

Samples

During the ATOS cruise (European project VENTOX) on the Rainbow field (36 $\left.13^{\prime} \mathrm{N} 33^{\circ} 54 \mathrm{~W}, 2275 \mathrm{~m}\right)$ located on the Mid-Atlantic Ridge (MAR), an active black smoker was collected by the Remotely Operated Vehicle (ROV) Victor, and brought to the surface in an insulated box under aseptic conditions. On board, eight fragments of the chimney were subsampled according to mineral zonations from the inner part to the outer part. The subsamples were crushed in an anaerobic chamber (La Calhene, France) and stored in sterile serum vials filled with sterile seawater containing $0.5 \mathrm{mg} \mathrm{l}^{-1}$ of $\mathrm{Na}_{2} \mathrm{~S}$. All subsamples were pooled to represent the whole chimney and this suspension was used to inoculate the enrichment cultures.

Continuous enrichment culture in bioreactor: conditions and monitoring

\section{Medium}

The growth medium was the modified SME medium (Sharp and Raven 1997) in which yeast and peptone were replaced by: $1 \mathrm{~g}$ yeast extract (Difco), $0.5 \mathrm{~g}$ casaminoacids (Difco), $0.4 \mathrm{~g}$ glucose, $0.4 \mathrm{~g}$ dextrin (from corn), 0.2 $\mathrm{g}$ galactose, $0.2 \mathrm{~g}$ dextran, $0.1 \mathrm{~g}$ glycogen, $0.2 \mathrm{~g}$ pyruvate and $0.1 \mathrm{~g}$ acetate (all purchased from Sigma). The medium was supplemented with $3 \mathrm{~g}^{-1}$ colloidal sulphur.

\section{Culture conditions}

The medium was sterilized by filtration (Sartroban, $0.22 \mu \mathrm{m}$ ) in a 20 litre Nalgene bottle containing the colloidal sulphur, previously sterilized by heating twice at $100^{\circ} \mathrm{C}$ for $30 \mathrm{~min}$ on two successive days. The culture was performed at $60^{\circ} \mathrm{C}$ and $\mathrm{pH} 6.5$ in a 2 litre glass gas -lift bioreactor as previously described (Raven et al. 1992; Godfroy et al. 2005). The bioreactor was inoculated at $2 \%(\mathrm{v} / \mathrm{v})$ with the chimney sample suspension. The temperature was controlled by a heated circulating bath filled with water and monitored with a standard PT100 
probe covered with Teflon. The $\mathrm{pH}$ was monitored using a combination gel $\mathrm{pH}$ electrode (Mettler Toledo). Acid $(1 \mathrm{~N} \mathrm{HCl})$ and base $(1 \mathrm{~N} \mathrm{NaOH})$ were added with peristaltic pumps (Masterflex). Temperature and $\mathrm{pH}$ were controlled with a 4-20 mA controller and AFS Biocommand system from New Brunswick (Nijmegen, Netherlands). Fresh medium addition and culture withdrawal were performed using peristaltic pumps (Masterflex). The culture was sparged with $\mathrm{N}\left(0.1 \mathrm{v} \mathrm{v}^{-1} \mathrm{~min}^{-1}\right)$ to maintain anaerobic conditions, and to eliminate volatile metabolic end products that might inhibit the growth of microorganisms (i.e. $\mathrm{H}_{2} \mathrm{~S}$ ). The bioreactor was maintained as a batch culture for the first $34 \mathrm{~h}$ to prevent wash-out of the cells before they have grown. After $34 \mathrm{~h}$, fresh medium was provided by applying a dilution rate of $0.04 \mathrm{~h}^{-1}\left(80 \mathrm{ml} \mathrm{h}^{-1}\right)$. To test the effect of the temperature on the composition of the cultivated microbial community, the temperature was increased from $60^{\circ} \mathrm{C}$ to $70^{\circ} \mathrm{C}$ at $\mathrm{T} 31$ (day 31 ) and to $80^{\circ} \mathrm{C}$ at $\mathrm{T} 36$ (day 36).

\section{Culture monitoring and sample preservation}

The culture was maintained for 45 days. Culture samples from the bioreactor were collected every 24 hours, from T0 (day 0) to T45 (day 45). Cell concentration was determined every day by direct cell counting, using a Thoma chamber (0.02 mm depth) viewed with an Olympus BX60 phase contrast microscope $(\times 400)$. For each sampling, $10 \mathrm{ml}$ of culture were preserved anaerobically at $4{ }^{\circ} \mathrm{C}$ in a serum vial, and eight cryotubes containing each $1.8 \mathrm{ml}$ of culture were frozen at $-20^{\circ} \mathrm{C}$ with $5 \%$ DMSO (v/v). For DNA extraction, cells were recovered from $15 \mathrm{ml}$ of culture by centrifugation $(20 \mathrm{~min}$ at $8,000 \mathrm{~g})$. Cell pellets were washed with $23 \mathrm{~g} \mathrm{l}^{-1}$ sterile $\mathrm{NaCl}$,

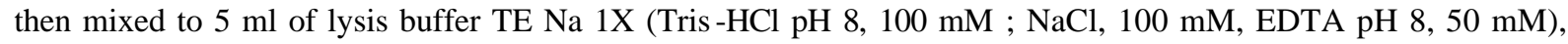
and stored at $-20^{\circ} \mathrm{C}$ until the DNA extraction procedure was undertaken. For whole-cell hybridisation, $12 \mathrm{ml}$ of culture sample were fixed for two hours with $3 \%(\mathrm{v} / \mathrm{v})$ formaldehyde. Fixed cells recovered by centrifugation $(10$ min at 6,000 rpm) were washed with PBS buffer (phosphate-buffered: $8 \mathrm{~g} \mathrm{NaCl}, 0.2 \mathrm{~g} \mathrm{KCl}, 1.44 \mathrm{~g} \mathrm{Na}_{2} \mathrm{HPO}_{4}$, $0.24 \mathrm{~g} \mathrm{KH}_{2} \mathrm{PO}_{4}$, per litre of distilled water, $\mathrm{pH} 7.4$ ) before storage in $50 \%$ (v/v) ethanol in $\mathrm{PBS}$ at $-20^{\circ} \mathrm{C}$. For HPLC analyses, $1.5 \mathrm{ml}$ of culture sample was centrifuged (10 min at 10,000 rpm) and the supernatant was stored at $4^{\circ} \mathrm{C}$ until analysis.

Batch enrichment cultures in vial: conditions and monitoring

Cultures were performed anaerobically in $100 \mathrm{ml}$ serum vials (Godfroy et al. 1996), using the medium described for the enrichment culture in the bioreactor to which $6.05 \mathrm{~g} \mathrm{I}^{1}$ PIPES was added and colloidal sulphur was 
replaced by $10 \mathrm{~g} \mathrm{l}^{-1}$ sulphur powder. Inoculation was performed with $2 \%(\mathrm{v} / \mathrm{v})$ of the chimney sample suspension. The same temperature and $\mathrm{pH}\left(60^{\circ} \mathrm{C}, \mathrm{pH} 6.5\right)$ as in the bioreactor were used. Cell pellets dedicated to DNA extractions were recovered from $15 \mathrm{ml}$ of culture after $24 \mathrm{~h}$ (sample A1) and $41 \mathrm{~h}$ (sample A2) of incubation. The $24 \mathrm{~h}$ culture (A1) was subcultured for $17 \mathrm{~h}$ in vial in the same conditions (sample B).

Nucleic acid extraction

DNA was extracted from frozen cell pellets in lysis buffer (cells recovered from $15 \mathrm{ml}$ of culture, see procedure above). A modified version of the protocol described by Alain et al. (2002) was followed combining chemical and enzymatic lysis. For these culture samples, the applied lysis treatment was $1.5 \mathrm{~h}$ and $2.5 \mathrm{~h}$. Afterwards, intact cells could not be observed by microscopy. Supernatants from the $1.5 \mathrm{~h}$ and $2.5 \mathrm{~h}$ lysis were pooled and extracted twice with equal volumes of buffered ( $\mathrm{pH}$ 8.0) PCI (phenol/chloroform/isoamylic acid : 25/24/1) and once with an equal volume of chloroform. DNA was finally precipitated by addition of $70 \%$ (v/v) isopropanol. After centrifugation at $11,000 \times \mathrm{g}$ for $30 \mathrm{~min}$, DNA was air dried before being resuspended in $250 \mu \mathrm{TE} 1 \times$ buffer (10 mM Tris - $\mathrm{HCl}, 2 \mathrm{mM}$ EDTA, $\mathrm{pH} 7.5)$. The extracted DNA quality was routinely checked using $0.8 \%$ agarose-TAE-1× gels.

Amplification of the 16S rRNA gene and DGGE analysis

The variable v3 region of 16S rRNA genes from extracted DNA were amplified using the primers 341F-GC and 907R specific to the bacterial domain (Muyzer et al. 1993; Muyzer and Smalla 1998). The PCR procedure and the analysis of the fragments by DGGE using the Bio-Rad Dcode apparatus are described in Muyzer et al. (1993). Electrophoresis conditions, gel staining, DGGE band extraction, DNA reamplification, and PCR product purification were performed using the conditions described by Postec et al. (2005b).

Amplification of the 16S rRNA gene and cloning

Archaeal DNA was amplified using the primer A24F (5'-TTC CGG TTG ATC CTG CCG GA -3') and the reverse primer 1407R (5'-GAC GGG CGG TGW GTR CAA-3') or alternatively A23SR (5' -CTT TCG GTC GCC CCT ACT-3', position 257-234 on Thermococcus celer 23S rRNA gene sequence). Bacterial DNA was 
amplified using primer E8F (5' -AGA GTT TGA TCA TGG CTC AG-3') and the reverse primer U1492R (5'GTT ACC TTG TTA CGA CTT-3'). PCR reactions were performed on a Robocycler Gradient 96 (Stratagene) (Wery et al. 2002; Nercessian et al. 2003). PCR products were then checked on a $0.8 \%$ (w/v) agarose gel and directly cloned using the TOPO TA Cloning ${ }^{\circledR}$ kit (pCR2.1 vector), according to the manufacturer's instructions (Invitrogen). Clone libraries were constructed by transforming E. coli TOP10F' cells. An archaeal and a bacterial library were constructed from two culture samples from the enrichment culture in bioreactor named T7 and T28, collected respectively after 7 and 28 days of culture, and from each sample of enrichment cultures in vials (A1, A2 and B).

16S rRNA gene sequencing and phylogenetic analysis

DNA fragments obtained by DGGE were sequenced by Genome Express S.A. (Grenoble, France). From clone libraries, each clone was cultivated overnight at $37^{\circ} \mathrm{C}$ with shaking $(320 \mathrm{rpm})$ on deepwell microplates, in $1 \mathrm{ml}$ Luria Bertani broth $2 \mathrm{X}$ medium containing ampicillin $\left(50 \mu \mathrm{g} \mathrm{ml}^{-1}\right)$. Plasmids were extracted and purified using Montage Plasmid Miniprep 96 Kits (Millipore) and partially sequenced using the BigDye Terminator chemistry with an automated capillary sequencer (Applied Biosystem). Sequences were compared to all GenBank, RefSeq Nucleotides, EMBL, DDBJ and PDB sequences using the BLAST (http://www.ncbi.nlm.nih.gov/BLAST) network service (Altschul et al. 1990) in order to determine phylogenetic affiliations and detect chimeric sequences. Alignment of 16S rRNA gene sequences was performed using the CLUSTALW program (Thompson et al. 1994), then refined manually using the SEAVIEW program (Galtier 1996). Sequences displaying more than $97 \%$ similarity were considered to be related and grouped in the same phylotype. Complete $16 \mathrm{~S}$ rRNA gene sequences were obtained for the representative clone of each unique phylotype: the related partial sequences were first assembled using the SEQMAN module of the DNASTAR software (Madison, WI, USA), and the complete sequences were analysed with the BLAST program.

Whole-cell hybridisation

Fixed cells in PBS/ethanol 50\% (v/v) (fixation procedure described above) were diluted if necessary and filtered on a $0.2 \mu \mathrm{m}$ pore size white polycarbonate filter (Isopore Membrane Filters, Millipore) laying on a nitrocellulose membrane. After drying at room temperature, cells were hybridised with the archaeal universal probe ARCH915 
(5'-GTG CTC CCC CGC CAA TTC CT-3') labelled with indocarbocyanin (Cy3) (Eurogentec) as well as with the universal bacterial probe EUB338 (5'-GCT GCC TCC CGT AGG AGT-3') labelled with fluoresceinisothiocyanate (FITC) (Eurogentec). Whole-cell hybridisations were carried out at $46^{\circ} \mathrm{C}$ after addition of $1.5 \mu 1$ ARCH915 and $1.5 \mu \mathrm{l}$ EUB338 each at $50 \mathrm{ng} \mu \mathrm{l}^{-1}$ and $12 \mu \mathrm{l}$ hybridisation solution $[\mathrm{NaCl} 5 \mathrm{M}$ : $360 \mu \mathrm{l}$, Tris $-\mathrm{HCl} 1$ M pH 7.4: $200 \mu$ l, formamide: $400 \mu$ l, sodium dodecyl sulphate (SDS) 10\%: $1 \mu 1$, deionised water: $1039 \mu 1]$ onto each filter. After $2 \mathrm{~h}$ hybridisation, the filters were rinsed up $15 \mathrm{~min}$ at $48^{\circ} \mathrm{C}$ in a wash solution $(\mathrm{NaCl} 5 \mathrm{M}: 1.8$ ml, Tris - $\mathrm{HCl} 1 \mathrm{M} \mathrm{pH}$ 7.4: $5 \mathrm{ml}$, SDS 10\%: $25 \mu \mathrm{l}$, deionised water: $43.2 \mathrm{ml}$ ). After the hybridisation procedure, each sample was stained with $10 \mu \mathrm{l}$ of 4',6'-diamidino-2-phenylindole (DAPI $1 \mu \mathrm{g} \mathrm{ml} \mathrm{m}^{-1}$ ). After addition of Citifluor (Citifluor, UK) to the filters, the hybridised cells were viewed with an Olympus microscope (BX60) equipped with a UV lamp and filters for DAPI (excitation $365 \mathrm{~nm}$, emission $397 \mathrm{~nm}$ ), FITC (excitation $492 \mathrm{~nm}$, emission $520 \mathrm{~nm}$ ), or Cy3 (excitation $550 \mathrm{~nm}$, emission $570 \mathrm{~nm}$ ).

Analyses of amino acids, organic acids, and glucose

The HPLC procedure used for analyses of amino acids, organic acids and glucose is in Wery et al. (2001).

\section{Gas analyses}

The gas outflow from the bioreactor was directly analysed using a MTI M200D micro gas chromatograph equipped with a thermal conductivity detector. A Molecular Sieve column with argon as the carrier gas was used at a temperature of $30^{\circ} \mathrm{C}$ to detect $\mathrm{H}_{2} \cdot \mathrm{CO}_{2}$ and $\mathrm{H}_{2} \mathrm{~S}$ were detected with a Poraplot $\mathrm{U}$ column at $100^{\circ} \mathrm{C}$, with helium as the carrier gas.

Subcultures and isolations

The media employed for the subcultures were designed to cultivate heterotrophic as well as autotrophic microorganisms that might be expected to grow with different electron acceptors (sulphur, nitrate, sulphate). Isolation of strains whose phylotypes were recovered in the clone libraries was attempted from the enrichment culture samples T7 and T28 from the bioreactor. Four culture media were used. The enrichment medium was used as described above and also according to the three following modifications. Vitamins and minerals were 


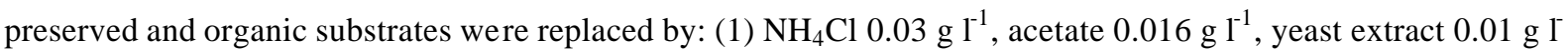
${ }^{1}$, and sulphur $5 \mathrm{~g} \mathrm{I}^{-1}$ in the DS medium, or (2) $\mathrm{NaNO}_{3} 0.2 \mathrm{~g} \mathrm{l}^{-1}$ in the DN medium, or (3) $\mathrm{Na}_{2} \mathrm{SO}_{4} 0.3 \mathrm{~g} \mathrm{l}^{-1}$ in the $\mathrm{T}$ medium. The DS, DN and $\mathrm{T}$ media were adjusted at $\mathrm{pH}$ 6.5. The DS medium was sterilized by tyndallisation (twice 30 min at $100^{\circ} \mathrm{C}$ ) while the $\mathrm{DN}$ and $\mathrm{T}$ media were autoclaved $\left(20 \mathrm{~min}\right.$ at $\left.121^{\circ} \mathrm{C}\right)$. In the anaerobic chamber, the media were reduced with $\mathrm{Na}_{2} \mathrm{~S}$ (final concentration: $0.05 \mathrm{~g} \mathrm{I}^{-1}$ ), then aliquoted into Hungate tubes or penicillin vials under $\mathrm{N}_{2} / \mathrm{H}_{2} / \mathrm{CO}_{2}$ (90:5:5). The gas phase was then replaced performing 10 cycles of vacuum extraction / addition of $\mathrm{H}_{2} / \mathrm{CO}_{2}\left(80 / 20\right.$, v/v, 2 bar). All the incubations were performed at $60^{\circ} \mathrm{C}$ and $\mathrm{pH} 6$. Strains were isolated by repeated dilutions-to-extinction cultures or streaking on solidified enrichment medium.

Nucleotide sequence accession numbers

The sequence data used in this study have been submitted to the EMBL databases under accession number AJ874300 to AJ874328.

\section{Results}

Monitoring of the continuous enrichment culture in bioreactor: cell morphologies, whole-cell hybridisation, DGGE, gas chromatography and HPLC

Starting from $2.710^{6}$ cell $\mathrm{ml}^{-1}$ at $\mathrm{T} 0$, cell density reached $7.410^{8} \mathrm{cell} \mathrm{ml}^{-1}$ at $\mathrm{T} 2$ and its maximal value $2.210^{9}$ cell $\mathrm{ml}^{-1}$ at $\mathrm{T} 31$ (Fig. 1). Coccoid cells single or in pairs were dominant at T2 (Fig. 2a, 2d). Afterwards rods displaying various morphologies became widely dominant (Fig. 2b, 2e). Short, rod-shaped cells appeared single or in chains within an outer sheath-like structure, similarly to the specific toga of Thermotogales. Long rods exhibiting a terminal endospore were observed. From T27, coccoid cells, single or in pairs, increased in density compared to the rod morphologies. At the end of the culture, rod morphologies had nearly disappeared.

The relative proportions of archaeal and bacterial cells were determined by whole-cell hybridisation in eleven culture samples of the bioreactor, from T2 to T41 (Fig. 1). Approximately 2,000 cells were counted on filters for each sample. $99.0 \%$ of the cells detected at T2 belonged to the Archaea (Fig. 2a, 2d); Bacteria were dominant from T4 to T31 (between 94.8 to $99.8 \%$ until T24, then $60.0 \%$ at T28 and 54.6\% at T31). At T36 and T41, Archaea became predominant again, representing $61.6 \%$ of the cells at $\mathrm{T} 36$ and $98.8 \%$ of the cells at $\mathrm{T} 41$. 
Temperature was increased from $60^{\circ} \mathrm{C}$ to $70^{\circ} \mathrm{C}$ at $\mathrm{T} 31$, and from $70^{\circ} \mathrm{C}$ to $80^{\circ} \mathrm{C}$ at $\mathrm{T} 36$, which was associated with a significant decrease in the cell density $\left(2.210^{9} \mathrm{cell} \mathrm{ml}^{-1}\right.$ at $\mathrm{T} 31$ and $1.810^{7} \mathrm{cell} \mathrm{ml}^{-1}$ at T41).

The forty-five days enrichment culture was further investigated by DGGE analysis. The v3 hypervariable region of the bacterial 16S rRNA gene was amplified from T1, T4, T9, T13, T16, T24, T28, T31 and T36 culture samples. No amplification was obtained from samples collected after T36, probably due to the low cell density corresponding to the temperature increase at T36. Representative DGGE bands migrating at different distances and originating from various samples were extracted from gels (not shown) and re-amplified directly. The DGGE sequence types (approximately $500 \mathrm{pb}$ ) were affiliated to Thermosipho MV1063 (99\% identity), Marinitoga camini (96\%), Caminicella sporogenes (99-98\%) and Deferribacter abyssi (87\%). Thermosipho spp. was detected from T1 to T36, Marinitoga spp. at T31, Caminicella spp. from T4 to T31 and Deferribacter spp. from $\mathrm{T} 1$ to $\mathrm{T} 31$.

$\mathrm{H}_{2}, \mathrm{CO}_{2}$ and $\mathrm{H}_{2} \mathrm{~S}$ were detected in T8, T21, T30 and T38 samples by gas chromatography. $\mathrm{H}_{2} \mathrm{~S}$ production was also detected using Zn acetate strips (Lead Acetate, Whatman) from T2 until the end of the culture. From T3 until T41, HPLC analysis of the free amino acids in the culture medium showed that they were all completely consumed, and might be therefore a limiting factor for microbial growth. Analysis of glucose by HPLC indicated an initial concentration of $0.440 \mathrm{~g}^{-1}$, between $\mathrm{T} 4$ and $\mathrm{T} 32$ glucose was not detected at all showing a complete consumption, and endly detected again and reaching $0.389 \mathrm{~g} \mathrm{t}^{-1}$. Also organic acids as pyruvate, succinate, lactate, formate, acetate, propionate, butyrate, isobutyrate and isovalerate were detected and assumed to be metabolic end products.

16S rRNA gene libraries from the continuous enrichment culture in bioreactor

Archaeal and bacterial 16S rRNA genes were amplified from T7 and T28 culture samples from the continuous enrichment culture in bioreactor. All the archaeal sequences from T7 and T28 were related to the genus Thermococcus (Table 1). The sequence types A704 and A800 were affiliated to T. siculi, and shared more than $97 \%$ of identity with a large number of $16 \mathrm{~S}$ rRNA gene sequences related to members of the group $T$. siculi T.celer, according to the BLAST analysis. Bacterial sequences affiliated with the orders Clostridiales, Thermotogales and Deferribacterales were retrieved in both T7 and T28 libraries (Table 1, Fig. 3) and were closely related to the hydrothermal species Caminicella sporogenes (97\% 16S rRNA gene identity with clones 775 and 813), Marinitoga camini (94\% identity with the clone 716, 95\% with clone 805) and Deferribacter 
abyssi (98\% identity with clones 737 and 820), respectively. The proportion of clones related to Deferribacter spp. and Marinitoga spp. increased slightly at T28, while the number of clones related to Caminicella spp. decreased from $50 \%$ to $7 \%$ (Fig. 3). Two phylotypes were recovered only in the T28 bacterial library: (i) 12 clones were affiliated to Thermosipho spp. and the sequence type 840 shared $99 \%$ identity with Thermosipho MV1063, the closest species being T. melanesiensis (96\% identity) and (ii) 3 clones were affiliated to Thermodesulfatator spp. and the sequence type 850 shared $96 \%$ identity with $T$. indicus (Table 1 ).

16S rRNA gene libraries from the batch enrichment cultures in vials

Total DNA was extracted from A1, A2 and B culture samples. Archaeal 16S rRNA gene was amplified by PCR only from sample A1, corresponding to the shortest incubated enrichment culture ( $24 \mathrm{~h}$ incubation). No archaeal 16S rRNA gene sequences was amplified after longer incubation (A2: $41 \mathrm{~h}$ incubation), and after subculturing from A1 (B). The 55 archaeal clones from the A1 library were all related to the genus Thermococcus (Table 1). The sequence type A254 displayed $97 \%$ identity with the closest described strain T. barophilus (AY099172), also originating from the Mid-Atlantic Ridge (Snake Pit) (Marteinsson et al. 1999) and growing in the range of $48-95^{\circ} \mathrm{C}$ under atmospheric pressure. Bacterial $16 \mathrm{~S}$ rRNA gene was amplified by PCR from all three samples. Sequences related to Marinitoga spp. and Caminicella spp. were retrieved in each library. Sequences related to the Thermosipho spp. were not recovered in the A1 culture, but only after 41 hours of incubation (A2) and after $17 \mathrm{~h}$ subculturing (B). Moreover, a shift was observed in the library compositions; sequences related to Marinitoga spp. were widely dominant in the A1 library whereas the A2 and B libraries were largely dominated by sequences related to Caminicella spp. (Fig. 3). Extending the incubation time or subculturing from the primary A1 culture resulted in similar changes in the composition of the bacterial libraries.

Subcultures and isolations

Several strains were isolated from culture samples (T3, T7 and T28) from the bioreactor: (i) an archaeal strain Thermococcus spp. designated as AT1273 (99\% 16S rRNA gene similarity with Thermococcus siculi) (ii) a strain Thermosipho spp. (order Thermotogales) designated as AT1272 (98\% similarity with Thermosipho MV1063, 95\% with T. melanesiensis) (iii) a new bacterial species of the Marinitoga genus (order Thermotogales) named M. hydrogenitolerans (Postec et al. 2005c); (iv) using the T medium, a new bacterial 
species among the Thermodesulfatator genus capable of sulphate-reduction $(96 \%$ similarity with the hydrothermal species $T$. indicus), (v) using the DS and DN media, we isolated a strain closely affiliated to the hydrothermal species Deferribacter abyssi (99\% identity).

\section{Discussion}

In this study, we used an original culture method to enrich thermophilic microorganisms from a hydrothermal black smoker: a continuous culture was performed in a gas-lift bioreactor during 45 days at $60^{\circ} \mathrm{C}$ and $\mathrm{pH} 6.5$ under anaerobic conditions. The microbial diversity in continuous culture and classical batch cultures in vials was compared.

\section{Methodological considerations}

The molecular inventories gave snapshots of the microbial diversity on a restricted number of samples while DGGE and whole-cell hybridisation revealed a temporal dynamics in the continuous culture. The use of different molecular techniques based on 16S rRNA gene analysis gave complementary data. For example, sequences of Thermosipho spp. were detected by DGGE at T7 in the bioreactor but were not evidenced by cloning. Inversely, Thermodesulfatator spp. was detected by cloning but not by DGGE. The possible limitations of primer selectivity and cloning biases (Theron and Cloete 2000) or PCR biases (Suzuki and Giovannoni 1996) are well established and can explain the variability in results from different methods.

Considering the gas-lift bioreactor as a system for continuous cultivation, the potential adhesion of bacteria on the inner wall and the formation of a biofilm have to be examined, since the bioreactor includes no device to clean surfaces. From a precipitate sampled on the inner wall, no cells were detected by microscopy observation. Culture attempt in vial and DNA extraction failed as well. X-RD analysis indicated that the precipitate was mainly composed of sulphurs (data not shown). The microorganisms detected in this study represent therefore cells in suspension. The dilution rate applied in the bioreactor after $34 \mathrm{~h}$ of batch culture was $0.04 \mathrm{~h}^{-1}$ and corresponded to a generation time of $17.25 \mathrm{~h}$. Although the continuous culture involves a progressive dilution of the medium inside the bioreactor, four volume changes, corresponding to $100 \mathrm{~h}$ (about 4 days) at a dilution rate of $0.04 \mathrm{~h}^{-1}$, have been considered sufficient to completely renew the culture medium inside the bioreactor (Raven 
et al. 1992). Thus, microorganisms thriving in the continuous culture from T6 were not washed-out and should have grown with a minimal growth rate of $0.04 \mathrm{~h}^{-1}$.

Thermococcales as early heterotrophic colonizers

Thermococcales at deep-sea hydrothermal vents are widespread and members of the genus Thermococcus are some of the most numerous hyperthermophiles described from deep-sea vents. Investigation of their natural distribution showed that a viable Thermococcus population was present in the surface layers of mature hydrothermal chimneys (Harmsen et al. 1997; Takai et al. 2001; Schrenk et al. 2003). The early growth of Thermococcales was observed in enrichment cultures from hydrothermal chimney performed in vials and bioreactor at $90^{\circ} \mathrm{C}$ (Postec 2005b) and at $60^{\circ} \mathrm{C}$ (this study). Although all the members of the Thermococcales are hyperthermophilic, their early growth at $60^{\circ} \mathrm{C}$ both in the bioreactor and in vials is possible since (i) some Thermococcus sp. are able to grow at $60^{\circ} \mathrm{C}$ (Godfroy et al. 1997), (ii) an absence of latency phase could explain the early growth (T. hydrothermalis; Godfroy, pers. com.), (iii) the number of Thermococcus-related cells might be abundant in the chimney sample used as inoculum. This is also suggested by the detection of Thermococcus spp. in the molecular inventory performed directly on the studied chimney sample, while the bacteria grown in this study were not detected (Postec $2005 \mathrm{~d}$ ). Their growth at $60^{\circ} \mathrm{C}$ at the beginning of the enrichment culture and then when temperature was ris en from 60 to $80^{\circ} \mathrm{C}$ after T31 may confer on Thermococcales a great ecological advantage to colonize new hydrothermal environments and they may be the first heterotrophs colonizing this ecosystem. This idea is supported by a recent study of nascent vent colonization in which protochimneys were deployed for short time on hydrothermal vents and heterotrophic groups including Thermococcales dominated the colonization of mineral surfaces after $72 \mathrm{~h}$ (McCliment et al. 2006). The temporal sequence of colonization was analysed in the study of in situ samplers deployed on hydrothermal vents: the widespread occurrence of Thermococcales was demonstrated in short deployments (4-7 days) and decreased with time, suggesting that this group is an early surface colonizer (Nercessian et al. 2003).

Bacterial diversity and insight into microbial interactions

All the bacteria cultivated in this study were related to microorganisms from deep-sea hydrothermal vents. Caminicella spp. and Marinitoga spp. were detected in both vials and bioreactor, while the autotrophs 
Deferribacter spp. and Thermodesulfatator spp. were only detected in the bioreactor. Compared to batch cultures in vials, a larger diversity was described in the enriched community in bioreactor continuous supply of nutrients, gaseous inhibitory by-products removal and and $\mathrm{pH}$ regulation over time, what confirms previous results (Postec et al. 2005b).

Guided by the results of the molecular analysis, we succeeded in isolating microorganisms (heterotrophs and autotrophs) enriched in continuous in the gas-lift bioreactor. Three new species belonging to the genera Thermosipho, Marinitoga and Thermodesulfatator were obtained in pure culture in vials. They were related to $T$. melanesiensis and M. camini, both originating from Atlantic deep sea vents, and T. indicus, isolated from the Central Indian Ridge, respectively. Marinitoga sp. nov. was recently characterised and named $M$. hydrogenitolerans because its growth is not inhibited by high hydrogen concentrations (Postec et al. 2005c). The genus Thermodesulfatator is only represented so far by the species $T$. indicus, a thermophilic, anaerobic and strictly chemolithoautotrophic bacterium growing exclusively with $\mathrm{CO}_{2}$ as sole carbon source, $\underline{\mathrm{H}}$ as sole electron donor and sulphate as sole electron acceptor (Moussard et al. 2004). A second chemolithoautotrophic to mixotrophic strain isolated from the bioreactor shared 99\% 16S rRNA gene similarity with Deferribacter abyssi (Miroshnichenko et al. 2003). D. abyssi is thermophilic, anaerobic and facultative chemolithoautotrophic using elemental sulphur or nitrate as electron acceptors, similarly to the strain isolated in this study.

In the enrichment culture, growth of Thermococcales clearly occurred first. Their fermentative metabolism on proteinaceous substrates and in smaller extent carbohydrates through sulphur reduction might have generated a propitious environment for the growth of bacterial heterotrophs Caminicella spp., Thermosipho spp. and Marinitoga spp) and then autotrophs (Deferribacter spp. and Thermodesulfatator spp.). The growth of Thermosipho sp. and Marinitoga sp. is correlated with the diminution of the glucose concentration in the medium and species of these genera are known to be able to use glucose as carbon substrate and to produce acetate as end metabolic product (Antoine et al. 1997; Alain et al. 2002b; Postec et al. 2005c).

Indeed 16S rRNA gene sequences related to the autotrophic microorganisms were detected by molecular analysis late at T28 but not at T7. Similarly, a temporal study of in situ collectors deployed on deep-sea hydrothermal vents showed that the microbial diversity of the colonizing community increased with time and that chemolithoautotrophs emerged during late stages (Nercessian et al. 2003).

The late growth of chemolithotrophs in co-culture with heterotrophs may be explained by interactions between species by means of metabolites exchanges. Organic carbon provided by the medium supported the growth of heterotrophs, afterwards the chemolithotrophs utilized carbon dioxide or acetate as carbon source and hydrogen 
and acetate as possible electron donor, both compounds being end-products of fermentation. The study of a natural community showed that acetate and a range of other organic electron donors can be oxidised under sulphate-reducing conditions in hydrothermal vents at high temperature $\left(90^{\circ} \mathrm{C}\right)$ (Tor et al. 2003). It has been suggested that acetate and hydrogen are the most prevalent organic fermentation products and important extracellular intermediates in the degradation of organic matter in hot microbial ecosystems, and that cooperative activity between fermentative microorganisms and sulphate reducers is important for the metabolism of fermentable compounds. Syntrophic interactions can also have an impact in hyperthermophilic co-cultures, for example on the metabolism of heterotrophic microorganisms co-cultivated with methanogens (Johnson et al. 2006).

\section{Conclusions}

A gas-lift bioreactor was used to cultivate in continuous a thermo philic microbial community from a deep sea hydrothermal chimney, on an organic-rich medium with sulphur under anaerobic conditions. The enrichment culture was monitored with molecular and chemical analyses. In the long-term running culture, the cultivated populations were evidenced to continuously evolve with time, instead of reaching a stationary state. Thermococcales dominated in the first hours of the enrichment cultures suggesting that this group early colonizes hydrothermal edifices, and may represent the first heterotrophic colonizers. A larger diversity was detected in the enrichment culture in bioreactor compared to culture in vials and most of the microorganisms enriched in bioreactor, including three new bacterial species, were successfully isolated by subculturing in vials. Results indicate that the continuous culture in a gas-lift bioreactor, combined with the use of molecular tools, could be of further use to access the "uncultivated" microbial community. The microorganisms isolated in this study displayed a phylogenetic and metabolic diversity. They are involved in the sulphur cycle (suphur- and sulphate-reduction) and in the carbon cycle (autotrophy and heterotrophy). Autotrophic microorganisms were enriched in co-culture with heterotrophs, suggesting that prokaryotic species interact by means of metabolite exchange to support the growth of autotrophs. This emphasizes the importance of microbial interactions with surrounding microorganisms, animals or minerals within ecological niches. Inter-species interactions should be further taken into account to attempt the growth of as-yet uncultivated microorganisms and microbial metabolism need to be examined inside communities rather than extrapolated from pure cultures (Tor et al. 2003). The bioreactor can be considered as a window to investigate in vitro interactions between population 

encompassing intense thermal and chemical gradient (Karl 1995), the microbial communities inhabiting these disturbed systems must be strongly affected by environmental changes. The gas-lift bioreactor represents a promising tool to investigate in vitro the effect of physico-chemical perturbations on the microbial community structure.

441

Acknowledgements The authors want to thank P.M. Sarradin, chief scientist of the ATOS cruise, as well as the captain and crew of the RV/Atalante and the Victor team. This work was supported by Ifremer, European VENTOX Program and Région Bretagne. We also wish to thank Dr C. L. Van Dover and Dr G. Webster for their helpful reading of the manuscript.

446

447 


\section{References}

Alain K, Olagnon M, Desbruyeres D, Page A, Barbier G, Juniper SK, Querellou J, Cambon-Bonavita MA (2002) Phylogenetic characterization of the bacterial assemblage associated with mucous secretions of the hydrothermal vent polychaete Paralvinella palmiformis. FEMS Microbiol Ecol 42:463-476

Altschul SF, Gish W, Miller W, Meyers EW, Lipman DJ (1990) Basic Local Alignment Search Tool. J Mol Biol 215:403-410

DeChaine EG, Bates AE, Shank TM, Cavanaugh CM (2006) Off-axis symbiosis found: characterization and biogeography of bacterial symbionts of Bathymodiolus mussels from Lost City hydrothermal vents. Environ Microbiol 8:1902-1912

Galtier N, Gouy M, Gautier C (1996) SEAVIEW and PHYLO_WIN: two graphic tools for sequence alignment and molecular phylogeny. CABIOS 12:543-548

Godfroy A, Meunier JR, Guezennec J, Lesongeur F, Raguénès G, Rimbault A, Barbier G (1996) Thermococcus fumicolans sp. nov. a new hyperthermophilic archaeum isolated from deep-sea hydrothermal vent in North Fiji bassin. Int J Syst Bacteriol 46:1113-1119

Godfroy A, Lesongeur F, Raguénès G, Quérellou J, Antoine E, Meunier JR, Guezennec J, Barbier G (1997) Thermococcus hydrothermalis sp. nov., a new hyperthermophilic archaeon isolated from deep-sea hydrothermal vent. Int J Syst Bacteriol 47:622-626

Godfroy A, Raven NDH, Sharp RJ (2000) Physiology and continuous culture of the hyperthermophilic deep-sea vent archaeon Pyrococcus abyssi ST549. FEMS Microbiol Lett 186:127-132

Godfroy A, Postec A, Raven NDH (2005) Growth of hyperthermophilic microorganisms for physiological and nutritional studies. In: Rainey FA, Oren A (eds) Methods in Microbiology, Extremophiles. Academic Press, Oxford, pp 91-106

Harmsen HJM, Prieur D, Jeanthon C (1997) Distribution of microorganisms in deep-sea hydrothermal vent chimneys investigated by whole-cell hybridization and enrichment culture of thermophilic subpopulations. Appl Environ Microbiol 63:2876-2883

Inagaki F, Kuypers MMM, Tsunogai U, Ishibashi JI, Nakamura KI, Treude T, Ohkubo S, Nakaseama M, Gena K, Chiba H, Hirayama H, Nunoura T, Takai K, Jorgensen BB, Horikoshi K, Boetius A (2006) Fro m the Cover: Microbial community in a sediment-hosted $\mathrm{CO}_{2}$ lake of the southern Okinawa Trough hydrothermal system. PNAS 103:14164-14169

Johnson MR, Conners SB, Montero CI, Chou CJ, Shockley KR, Kelly RM (2006) The Thermotoga maritima phenotype is impacted by syntrophic interaction with Methanococcus jannaschii in hyperthermophilic coculture. Appl Environ Microbiol 72:811-818

Karl DM (1995) Ecology of free-living hydrothermal vent microbial communities. In: Karl DM (eds) The microbiology of deep-sea hydrothermal vents. CRC Press, pp 35-125

Kormas KA, Tivey MK, Von Damm K, Teske A (2006) Bacterial and archaeal phylotypes associated with distinct mineralogical layers of a white smoker spire from a deep-sea hydrothermal vent site $\left(9^{\circ} \mathrm{N}\right.$, East Pacific Rise). Environ Microbiol 8:909-920

López-García P, Duperron S, Philippot P, Foriel J, Susini S, Moreira D (2003) Bacterial diversity in hydrothermal sediment and epsilon-proteobacterial dominance in experimental microcolonizers at the MidAtlantic Ridge. Environ Microbiol 5:961-976

Marteinsson V, Birrien J, Reysenbach A, Vernet M, Marie D, Gambacorta A, Messner P, Sleytr U, Prieur D (1999) Thermococcus barophilus sp. nov., a new barophilic and hyperthermophilic archaeon isolated under high hydrostatic pressure from a deep-sea hydrothermal vent. Int J Syst Bacteriol 49:351-359

McCliment EA, Voglesonger KM, O'Day PA, Dunn EE, Holloway JR, Cary SC (2006) Colonization of nascent, deep-sea hydrothermal vents by a novel archaeal and nanoarchaeal assemblage. Environ Microbiol 8:114-125

Miroshnichenko ML, Slobodkin AI, Kostrikina NA, L'Haridon S, Nercessian O, Spring S, Stackebrandt E, Bonch-Osmolovskaya EA, Jeanthon C (2003) Deferribacter abyssi sp. nov., an anaerobic thermophile from deep-sea hydrothermal vents of the Mid-Atlantic Ridge. Int J Syst Evol Microbiol 53:1637-1641

Moussard H, L'Haridon S, Tindall BJ, Banta A, Schumann P, Stackebrandt E, Reysenbach AL, Jeanthon C (2004) Thermodesulfatator indicus gen. nov., sp. nov., a novel thermophilic chemolithoautotrophic sulfatereducing bacterium isolated from the Central Indian Ridge. Int J Syst Evol Microbiol 54:227-233

Moussard H, Corre E, Cambon-Bonavita MA, Fouquet Y, Jeanthon C (2006) Novel uncultured Epsilonproteobacteria dominate a filamentous sulphur mat from the $13^{\circ} \mathrm{N}$ hydrothermal vent field, East Pacific Rise. FEMS Microbiol Ecol 58:449-463

Muyzer G, Smalla K (1998) Application of denaturing gradient gel electrophoresis (DGGE) and temperature gradient gel electrophoresis (TGGE) in microbial ecology. Ant van Leeuw 73:127-141 
Muyzer G, De Waal EC, Uitterlinden AG (1993) Profiling of complex microbial populations by denaturing gradient gel electrophoresis analysis of polymerase chain reaction- amplified genes coding for 16S rRNA. Appl Environ Microbiol 59:695-700

Nercessian O, Reysenbach AL, Prieur D, Jeanthon C (2003) Archaeal diversity associated with in situ samplers deployed on hydrothermal vents on the East Pacific Rise $\left(13^{\circ} \mathrm{N}\right)$. Environ Microbiol 5:492-502

Pace NR, Stahl DA, Lane DJ, Olsen GJ (1986) The analysis of natural microbial populations by ribosomal RNA sequences. Adv Microbial Ecol 9:1-55

Postec A, Pignet P, Cueff-Gauchard V, Schmitt A, Querellou J, Godfroy A (2005a) Optimisation of growth conditions for continuous culture of the hyperthermophilic archaeon Thermococcus hydrothermalis and development of sulphur-free defined and minimal media. Res Microbiol 156:82-87

Postec A, Urios L, Lesongeur L, Ollivier B, Querellou J, Godfroy A (2005b) Continuous enrichment culture and molecular monitoring to investigate the microbial diversity of thermophiles inhabiting the deep-sea hydrothermal ecosystems. Curr microbiol 50:138-144

Postec A, Le Breton C, Fardeau ML, Lesongeur F, Pignet P, Querellou J, Ollivier B, Godfroy A (2005c) Marinitoga hydrogenitolerans sp. nov., a novel member of the order Thermotogales isolated from a black smoker chimney on the Mid-Atlantic Ridge. Int J Syst Evol Microbiol 55:1217-1221

Postec A (2005d) Diversité de populations microbiennes thermophiles d'une cheminée hydrothermale océanique: cultures d'enrichissement en bioréacteur et isolement d'espèces nouvelles. In: Thesis, Université de Provence, France

Raven N, Ladwa N, Sharp R (1992) Continuous culture of the hyperthermophilic archaeumPyrococcus furiosus. Appl Microbiol Biotechnol 38:263-267

Raven NDH, Sharp RJ (1997) Development of defined and minimal media for the growth of the hyperthermophilic archaeon Pyrococcus furiosus Vc1. FEMS Microbiol Lett 146:135-141

Schrenk MO, Kelley DS, Delaney JR, Baross JA (2003) Incidence and diversity of microorganisms within the walls of an active deep-sea sulfide chimney. Appl Environ Microbiol 69:3580-3592

Sharp RJ, Raven NDH (1997) Isolation and growth of hyperthermophiles. In: Rhodes PM, Stanbury PF (eds) Applied microbial physiology: a practical approach. IRL Press, Oxford, pp 23-51

Suzuki M, Giovannoni S (1996) Bias caused by template annealing in the amplification of mixtures of 16S rRNA genes by PCR. Appl Environ Microbiol 62:625-630

Takai K, Komatsu T, Inagaki F, Horikoshi K (2001) Distribution of Archaea in a black smoker chimney structure. Appl Environ Microbiol 67:3618-3629

Theron J, Cloete TE (2000) Molecular techniques for determining microbial diversity and community structure in natural environments. Crit Rev Microbiol 26:37-57

Thompson J, Higgins D, Gibson T (1994) CLUSTAL W: improving the sensitivity of progressive multiple sequence alignment through sequence weighting, position-specific gap penalties and weight matrix choice. Nuc Acids Res 22:4673-4680

Tor JM, Amend JP, Lovley DR (2003) Metabolism of organic compounds in anaerobic, hydrothermal sulphatereducing marine sediments. Environ Microbiol 5:583-591

Wery N, Cambon-Bonavita MA, Lesongeur F, Barbier G (2002) Diversity of anaerobic heterotrophic thermophiles isolated from deep-sea hydrothermal vents of the Mid-Atlantic Ridge. FEMS Microbiol Ecol 41:105-114

Wery N, Lesongeur F, Pignet P, Derennes V, Cambon-Bonavita MA, Godfroy A, Barbier G (2001) Marinitoga camini gen. nov., sp. nov., a rod-shaped bacterium belonging to the order Thermotogales, isolated from a deep-sea hydrothermal vent. Int J Syst Evol Microbiol 51:495-504 


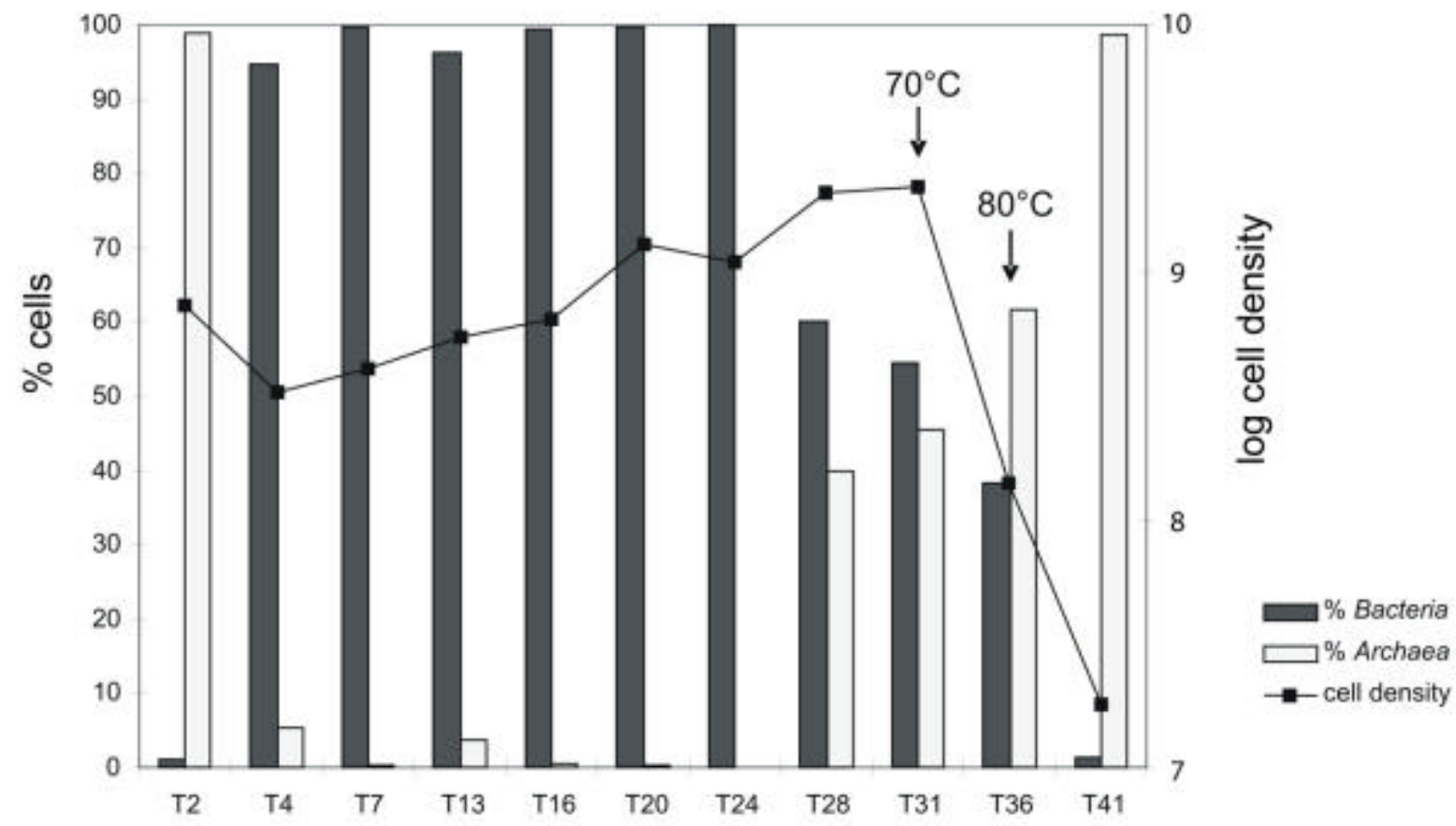

Time period

552

553 Fig. 1 Total cell densities of the bioreactor culture from T2 to T41 expressed in cell ml ${ }^{-1}$ and Archaea and Bacteria ratio expressed in percentages of total cells determined by whole-cell hybridisation using the universal probes ARC915 and EUB338 respectively. The temperature was increased from $60^{\circ} \mathrm{C}$ to $70^{\circ} \mathrm{C}$ at $\mathrm{T} 31$ and from

556 $70^{\circ} \mathrm{C}$ to $80^{\circ} \mathrm{C}$ at $\mathrm{T} 36$.

557 

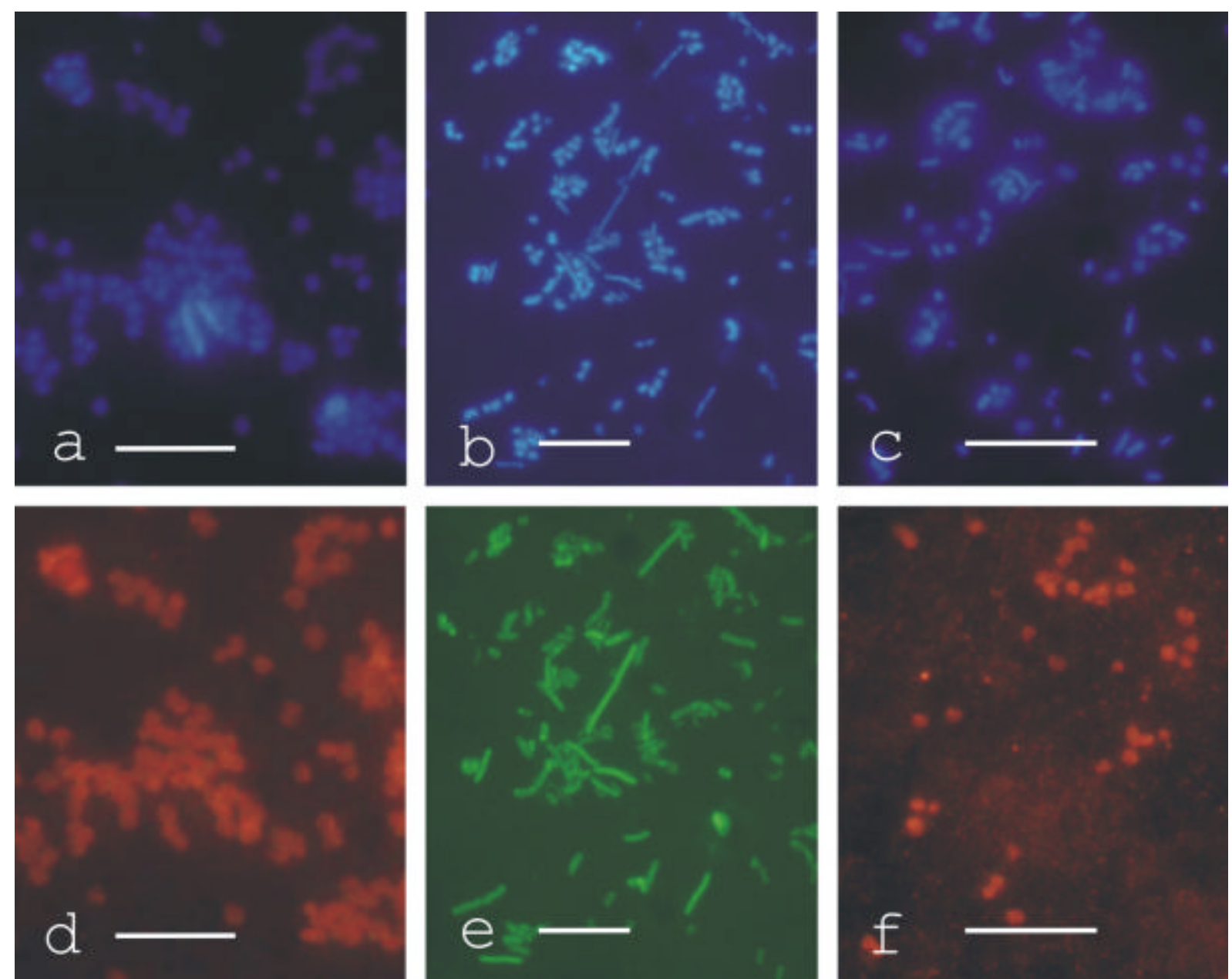

Fig. 2 Whole-cell hybridisation of fixed cells from 3 samples of the enrichment culture in bioreactor: T2 (a, d), T7 (b, e) and T28 (c, f). Cells were stained with DAPI (a, b and c), and hybridised with the FITC-labelled Eub338 probe (e), or the Cy-3-labeled Arch 915 (d and f). Cells were viewed by epifluorescence microscopy in which DAPI-, FITC- and Cy-3-specific filters were used. The relative proportions of archaeal and bacterial cells were determined by counting approximately 2,000 cells on filter and resulted in: $99.0 \%$ of the cells detected at T2 belonged to the Archaea (d), $99.0 \%$ of the cells detected at T7 belonged to the Bacteria (e), $40 \%$ of the cells detected at T28 belonged to the Archaea (f). Scale bars $=10 \mu \mathrm{m}$. 


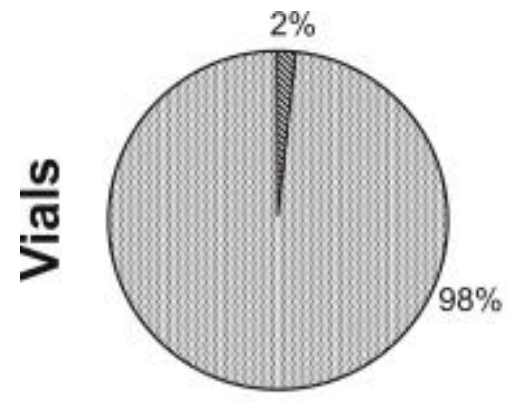

A1

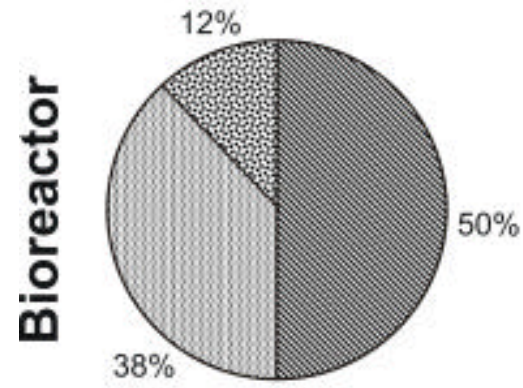

T7

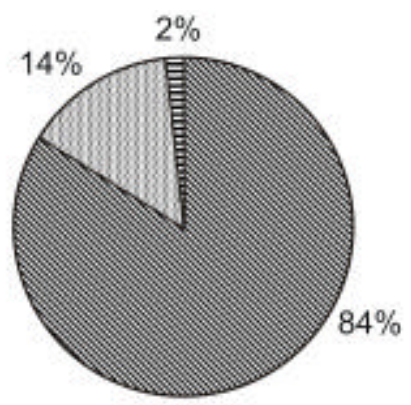

A2

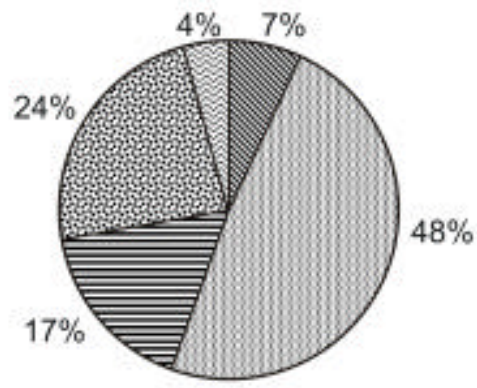

T28

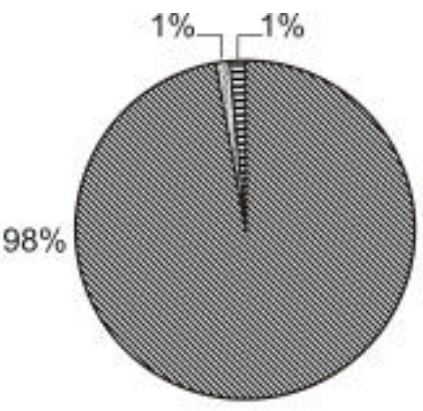

B

$\cong$ Caminicella spp

Marinitoga spp.

春 Thermosipho spp.

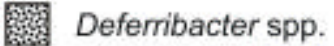

Thermodesulfatator spp.

Fig. 3 Composition of the bacterial clone libraries from enrichment cultures in vials (A1: 24 hours culture, A2: 41 hours culture and B: 17 hours subculture from A1) and from the enrichment culture in bioreactor (T7: 7 days culture, T28: 28 days culture). The percentages of clones of each phylogenetic group are indicated on the piecharts. 
578 Table 1. Distribution and phylogenetic affiliations of archaeal and bacterial 16S rDNA sequences $\gtrless$ 97\%

579 similarity in each phylotype) from the enrichment culture in bioreactor and from enrichment cultures in flask

580 both performed at $60^{\circ} \mathrm{C}$. Representative clones were completely sequenced. The sequence types deposited in

581 GenBank appear in bold.

582

\begin{tabular}{|c|c|c|c|c|c|c|}
\hline & $\begin{array}{l}\text { Culture } \\
\text { sample }\end{array}$ & $\begin{array}{l}\text { Phylogenetic } \\
\text { affiliation }\end{array}$ & Representative clones & $\begin{array}{l}\text { Number } \\
\text { of clones }\end{array}$ & Closest match organism $^{\text {a }}$ & $\begin{array}{c}\text { Identity }^{\mathrm{a}} \\
(\%)\end{array}$ \\
\hline \multirow{10}{*}{ 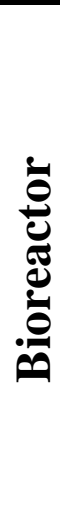 } & $\mathrm{T} 7$ & Thermococcales & $\begin{array}{l}\text { A704- A710-A712- A715- } \\
\text { A730-A732-A737-A739 }\end{array}$ & 76 & Thermococcus siculi (AY099185) & 98 \\
\hline & $\mathrm{T} 28$ & Thermococcales & A800-A811- A816-A817 & 71 & Thermococcus siculi (AY099185) & 98 \\
\hline & $\mathrm{T} 7$ & Clostridiales & 775-700-725-728-750-770- & 38 & Caminicella sporogenes (AJ320233) & 97 \\
\hline & & Thermotogales & 716-705-706-709-724-768 & 29 & Marinitoga camini (AJ250439) & 94 \\
\hline & & Deferribacterales & 737-711-740-754-769 & 9 & Deferribacter abyssi (AJ515882) & 98 \\
\hline & T28 & Clostridiales & 813-874 & 5 & Caminicella sporogenes (AJ320233) & 97 \\
\hline & & Thermotogales & $\mathbf{8 0 5}-802-822-823-832$ & 35 & Marinitoga camini (AJ250439) & 95 \\
\hline & & & 840-812-821-825-868-884- & 12 & Thermosipho MV1063 (AJ419874) & 99 \\
\hline & & Deferribacterales & 893 & 17 & Deferribacter abyssi (AJ515882) & 98 \\
\hline & & $\begin{array}{l}\text { Thermodesulfo- } \\
\text { bacteriales }\end{array}$ & $\begin{array}{l}\mathbf{8 2 0}-829-856 \\
\mathbf{8 5 0}-816-858\end{array}$ & 3 & $\begin{array}{l}\text { Thermodesulfatator indicus } \\
\text { (AF393376) }\end{array}$ & 96 \\
\hline \multirow{9}{*}{$\frac{y}{\tilde{E}}$} & A1 & Thermococcales & A254 & 55 & $\begin{array}{l}\text { Thermococcus barophilus } \\
\text { (AY099172) }\end{array}$ & 97 \\
\hline & A1 & Clostridiales & 238 & 1 & Caminicella sporogenes (AJ320233) & 97 \\
\hline & & Thermotogales & 207-245-219-240-255 & 58 & Marinitoga camini (AJ250439) & 94 \\
\hline & A2 & Clostridiales & 413-404-462 & 47 & Caminicella sporogenes (AJ320233) & 97 \\
\hline & & Thermotogales & 436 & 8 & Marinitoga camini (AJ250439) & 95 \\
\hline & & & $440^{b}$ & 1 & Thermosipho MV1063 (AJ419874) & 98 \\
\hline & B & Clostridiales & 608-626-669-635 & 68 & Caminicella sporogenes (AJ320233) & 97 \\
\hline & & Thermotogales & $660^{b}$ & 1 & Marinitoga camini (AJ250439) & 93 \\
\hline & & & 609 & 1 & Thermosipho MV1063 (AJ419874) & 97 \\
\hline
\end{tabular}

$584{ }^{\mathrm{b}}$ partial sequence $(600 \mathrm{pb})$ 